\title{
A Case Study Impact of liberalization on growth of sugar production and insatiability in sugarcane cultivation in India
}

- VIKRAM YOGI, RISHABH KUMAR AND RAVINDRA

See end of the paper for authors' affiliations

Correspondence to : VIKRAM YOGI Division of Agricultural Economics, Indian Agricultural Research Institute, NEW DELHI, INDIA

Email: agrico.vikramyogi @ gmail.com

\section{Paper History :}

Received : 31.07 .2015

Accepted : 30.08 .2015
AbSTRACT : Indian economy is mainly agro based but the economic reforms in the early nineties did not have any direct recommendations for agricultural sector. Sugarcane is one of the widely grown crop in India and India is second largest for sugar in the world. India's sugar policy significantly affects the sugar economy at the world level. Contrastingly, after liberalisation the sugar industry showed lower growth rate which may be due to technological, managerial and economical inefficiencies at farm as well as policy making levels. These are needed to be corrected based on the various expert committees' recommendations. The instability in area under sugarcane area and production was found low due adequate availability of irrigation in major states unlike other states. The pending arrears by mills are also responsible instability in production.

Key Words : Sugar, Sugarcane, Growth rate, Liberalisation, Instability

How To Cite This PAPer : Yogi, Vikram, Kumar, Rishabh and Ravindra (2015). Impact of liberalization on growth of sugar production and insatiability in sugarcane cultivation in India. Internat. Res. J. Agric. Eco. \& Stat., $6(2): 432-436$. 